\title{
Mekanisme Lipstik dalam Mewarnai dan Melembabkan Bibir
}

\author{
Nagina Belali \\ Program Magister Farmasi, Fakultas Farmasi, Universitas Padjadjaran, Sumedang, 45363 \\ email: nagina17001@mail.unpad.ac.id
}

\section{Abstrak :}

Lipstik adalah jenis kosmetik yang sangat populer pada wanita dan digunakan hampir oleh semua wanita setiap hari. Lipstik dirancang untuk memperbaiki penampilan alami bibir, menimbulkan perubahan warna, meningkatkan kilau dan menghaluskan garis keriput serta lipatan pada bibir. Dalam review artikel ini dijelaskan mengenai sejarah, mekanisme, komposisi dan formulasi lisptik dalam mewarnai dan melembabkan bibir.

Keyword : lipstik, kosmetik, bibir

\section{Pendahuluan}

Sejak zaman dahulu, pewarna bibir telah digunakan. Artefak dari warga Mesir awal, Babilonia dan Sumeria mengungkapkan bahwa Wanita di masyarakat ini melukis bibir mereka dengan campuran hematit dan oker merah pada lemak hewani atau minyak nabati.

Kosmetik bibir digunakan oleh orang Syria, Persia, Yunani dan Romawi untuk tujuan estetis, medis atau ritualistik.

Saat lipstik diaplikasikan, film produk lilin tertinggal di permukaan bibir. Komponen warna lipstik menghalangi warna permukaan alami, mengubahnya sementara menjadi komponen film yang membantu menjaga warna tetap menempel pada bibir.

\section{Bagaimana lipstik bekerja?}

Lipstik terbuat dari bahan hidrofobik (tidak larut air). Bila formula padat diterapkan pada permukaan bibir, gesekan akan mencairkannya dan memungkinkan untuk berpindah. Bahan akan mencair dan membentuk kembali sehingga menciptakan lapisan film yang melekat pada permukaan karena interaksi hidrofobik. Selain basis hidrofobik, warna merupakan bahan utama dalam lipstik.

Warnanya memantulkan cahaya dengan panjang gelombang tertentu untuk memberi kesan warna baru di permukaan. Silikon dan bahan berminyak juga ditambahkan untuk memantulkan cahaya dan memberi kilau.

\section{Komposisi lipstik}

Bahan utama dalam lipstik meliputi solidifier ( zat pembeku), minyak pengencer dan pewarna. Solidfier termasuk lilin seperti lilin lebah, wax Carnauba atau Candelilla. 
Wax memberikan lipstik dengan sifat leleh yang diinginkan (misalnya lipstik perlu solid pada suhu kamar namun dapat menyebar pada suhu kulit). Minyak pengencer digunakan untuk membantu pewarna merata. Contohnya minyak jarak atau ester jojoba. Pewarna termasuk dalam lipstik termasuk pewarna organik seperti pewarna Merah 7 atau anorganik seperti Red Iron Oxide.

Berbagai ramuan lainnya ditambahkan ke formula lipstik untuk memodifikasi karakteristik leleh, profil adhesi, stabilitas dan membuat produksi menjadi lebih mudah.

Jika lipstik digunakan untuk pemakaian yang lama, kemungkinan akan ada perubahan yang tidak diinginkan pada bibir. Misalnya kelebihan lilin di bibir bisa mencegah pelumasan alami, sehingga bibir akan mengering. Dengan demikian untuk meningkatkan efek pelembab dari lipstik DAN untuk mengatasi masalah yang disebutkan diatas, perlu penambahan air. Namun, karena lipstik bersifat hidrofobik dan kombinasi minyak dan air biasa disebut emulsi secara termodinamika tidak stabil, oleh karena itu perlu penambahan zat pengemulsi dari formulasi lipstik tersebut.

\section{Pengemulsi}

Banyak produk kosmetik didasarkan pada emulsi, tetesan minyak kecil terdispersi dalam air atau tetesan air kecil terdispersi dalam minyak.

Istilah pengemulsi mengacu pada bahan yang membantu untuk menjaga zat-zat yang tidak bisa bercampur seperti (seperti minyak dan air) sehingga dapat bercampur maka emulgator perlu ditambahkan untuk mengubah tegangan permukaan antara air dan minyak, sehingga menghasilkan produk yang homogen dan tercampur rata dengan tekstur yang rata. Contoh pengemulsi yang digunakan dalam kosmetik meliputi polisorbat, lauret-4, dan kalium setil sulfat.

\section{Contoh Formulasi Lipstik}

Lipstik memberikan efek pelembab yang bermanfaat, mudah diterapkan pada bibir, menyebar dan mengkoreksi bentuk bibir.

Formula Lipstik membentuk dasar gel / krim yang menggabungkan campuran minyak canola, ekstrak glycinesoja (soybean), pati Zea mays (jagung) dan silika.

Bagian komposisi yang paling penting adalah penggunaan sistem basis yang terdiri dari campuran minyak kista canola, ekstrak glycinesoja (soybean), pati Zea mays (jagung) dan silika untuk memberikan efek penuh dan lembut pada lipstik.

Minyak canola adalah minyak nabati dari biji canola yang sangat stabil, asam oleatnya tinggi, kaya akan vitamin $\mathrm{E}$ yang merupakan pelembab yang sangat baik untuk membantu mengurangi iritasi kulit. Vegelatum ${ }^{\circledR}$ Equiline adalah emolien alami yang dihasilkan dari minyak canola nontransgenik.

Canola gel lebih unggul dari emolien yang berasal dari mineral, seperti petrolatum, karena memiliki thermostability yang luar biasa, strukturnya seperti gel dan juga kurang berminyak.

Dalam kombinasi Dengan basis gel / krim lainnya, ia melembutkan dan menghaluskan kulit, membentuk fillm ringan yang mencegah penguapan uap air dari kulit dan melindungi kulit dari iritasi. Dalam penampilannya, canola gel bersifat off-white, gel buram, dengan bau yang sangat ringan. 
Komposisi lipstick juga dapat menggunakan satu atau lebih minyak atau emolien. Setiap minyak yang dapat digunakan dalam bidang farmasi atau kosmetik dapat digunakan pada basis Wax, Contoh minyak yang bersifat emolien diantaranya adalah, minyak jarak, minyak kelapa, minyak jagung, minyak jojoba, minyak biji kapas, minyak kedelai, minyak kenari, minyak biji gandum dan sebagainya. Pigmen yang dapat digunakan disini Semua warna anorganik dan organik / pigmen cocok untuk digunakan dalam komposisi komposisi lemak.

\section{Mekanisme Moisturisasi}

Pelembab atau emolien adalah campuran kompleks agen kimia ( membantu menahan penguapan air di kulit setelah aplikasi, menghasilkan kelembaban dan membantu menghaluskan kulit) yang dirancang khusus untuk membuat lapisan kulit luar (epidermis) lebih lembut dan lebih lentur.

Air dan emulgator yang mengemulsi air ke bagian lipstik hidrofobik membantu formulasi meningkatkan hidrasi bibir (kadar air) dengan mengurangi penguapan.

Wax, minyak nabati dan emolien membuat lapisan di bibir dan mencegah hilangnya air dan kelembapan alami bibir dandengan adanya emolien dalam formulasi membantu melembutkan dan menghaluskan bibir.

Banyak lipstik dan lip gloss juga mengandung bahan mineral dan logam berat seperti lead, nikel dan kobalt, serta kadmium dan kromium - keduanya dikenal sebagai karsinogen.

Zat ini selalu ada dalam produk sebagai 'zat pengotor', yaitu, ada dalam bahan lain seperti lilin, minyak atau pigmen mineral yang digunakan dalam formula. Karena sifat zat ini dan sifatnya yang terus-menerus terjadi dalam lingkungan alami, termasuk di dalam air, hampir tidak mungkin untuk menghapus semua jejaknya.

Zat pengotor dalam lipstik normal, tapi yang penting adalah tingkat pengotor ini harus diketahui dan dikendalikan. Jadi lipstik harus dipilih yang alami dan terkontrol kualitas, dan jumlah logam berat sudah diketahui di dalamnya.

Daftar Pustaka:

Orrea Light., "Lipstick Composition", United States Patent Application Publication (US 2003/0099604 A1), May 2003.

S. M., Rousseau. D., "Flocculation and coalescence in water-in-oil emulsions stabilized by paraffin wax crystals", Food Research International, August 2003.

Profesor Ben, Dr Oliver Jones. The chemistry of cosmetics. science.org.au 